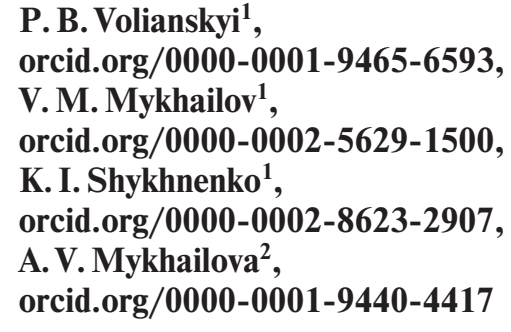

P. B. Volianskyi ${ }^{1}$, orcid.org/0000-0001-9465-6593, V. M. Mykhailov ${ }^{1}$, orcid.org/0000-0002-5629-1500, K. I. Shykhnenko ${ }^{1}$, orcid.org/0000-0002-8623-2907, A.V. Mykhailova ${ }^{2}$, orcid.org/0000-0001-9440-4417

1 - Institute of Public Administration in the Sphere of Civil Protection, Kyiv, Ukraine, e-mail: mvn2006@ukr.net 2 - Ukrainian Civil Protection Research Institute, Kyiv, Ukraine

\title{
KNOWLEDGE MANAGEMENT AS A TOOL TO ENSURE PUBLIC SAFETY IN EMERGENCIES
}

Purpose. The purpose of this article is to determine the theoretical and practical bases for knowledge management, which is a tool to ensure public safety during emergency response in Ukraine.

Methodology. This paper highlights the issue of knowledge management to achieve the goals of protecting the population and territories against natural and man-made hazards. When investigating the issue, the authors used basic research methods, namely statistical analysis (to represent the variables of the impact of emergencies on the lives of the population, economy and environment of the country); logical and systems analysis (to describe knowledge development and management, to determine the content of knowledge management to ensure public safety); generalization, analysis and synthesis (to study the existing knowledge management system). Method of individual expert estimation was used during interviews with emergency management experts, which resulted in development of relative importance of knowledge factors.

Findings. It has been found that knowledge management is a vital process to fulfill the purpose of protecting civilians and territories against natural and man-made disasters. Key knowledge factors on ensuring the safety of the civilian population in emergencies are classified in the main categories: legal, infrastructural, financial and economic, resource-based, organizational, social and political, and time. As a result of expert research, indicators of relative importance of the studied knowledge factors have been found out, which affect the safety of the civilian population during disaster management in Ukraine.

Originality. Based on logical analysis, the phenomenon of knowledge management to ensure public safety during emergency response in Ukraine has been clarified. The concept of "knowledge management for the safety of the civilian population during an emergency" is specified as a process in which any authorities or enterprises (institutions, organizations) being stakeholders in the field of civil protection generate and accumulate knowledge for the benefit of the safety of life and activities of the civilian population. Key knowledge factors on ensuring the safety of the civilian population during emergency response (legal, infrastructural, financial and economic, resource-based, organizational, social and political, and time) have been identified and it has been found that they can influence all the stages of the emergency management cycle. It has also been determined that the following knowledge factors, such as social and political, organizational and resource-based ones are very important for emergency response.

Practical value. Research findings can be taken into account by the heads of authorities, enterprises (institutions, organizations) whose work relates to organizing and running events in civil protection during emergency response, which will enhance the safety of the civilian population.

Keywords: emergency, public safety, knowledge factors, knowledge management

Introduction. The solution of urgent issues of politics and economics of the state is achieved through the progress of science, technology, and production. At the same time, it is replaced by the uncertainty of the situation related to the occurring of new natural, man-made or social issues. The growth of these challenges threatens daily activities of people, their health and life as well. At different stages of the history of Ukraine high living standards, human well-being and security have always been strategic goals for the development of the country. This remains a priority for the government but the importance of security, its essence for the quality of life have now increased significantly.

Over the past century, the number of emergencies in the world has been steadily increasing. Accordingly, loss of human life, people's homes and property, and the damage to physical infrastructure and the environment have grown. Emergency risk ignorance calls into question not only economic growth and social well-being, but also the country's national security. The population of Ukraine is under constant influence of natural, man-made, and social disasters, their embodiment in the military confrontation in eastern Ukraine. The devastating effects of emergencies on civilians' life, economy and environment of the country are not diminishing. During 2019, 146 disasters happened on the territory of Ukraine, as a result of which 199 people died and 1492 were injured [1]. As L. Pet-

(C) Volianskyi P. B., Mykhailov V.M., Shykhnenko K. I., Mykhailova A. V., 2020 renko argues, the impact of technological, demographic, social and economic changes makes significant adjustments to the employment landscape of different countries, causes the introduction of new skills requirements for specialists from different economic sectors [2].

Unsolved aspects of the problem. As people around the world are exposed to an increase in the frequency and variety of disasters and accidents, efforts to ensure their safety are aimed at avoiding or reducing possible losses, assisting victims, and achieving quick recovery. Authorities, enterprises (institutions, organizations), as stakeholders in civil protection, must make sufficient efforts to ensure the safety of the civilians during emergencies. Establishing of the effective counter disaster system contributes to the safe living conditions for people, as well as sustainable development of the country's economy. Effective measures development to protect the civilian population requires to enhance highly effective advanced management technologies used by government agencies, enterprises (institutions, organizations). One such technology is knowledge management, which is widely used in the developed countries.

At the main stages of the disaster countering, starting with the pre-crisis period, essential and timely information to make coordinated decisions is always of importance. Knowledge leads to collaboration between various stakeholders in civil protection in order to prevent, respond to emergencies and eliminate their consequences, to carry out rehabilitation work. With the experience gained by dealing with disasters, they acquire 
knowledge, which is necessary to ensure life safety of the civilian population. Emergency elimination generates and accelerates new specialized knowledge development based on security values. Such knowledge is of particular significance, a strategically important asset under the natural and man-made threats.

Researchers claim that the ability to generate and use new knowledge productively is the basis for national competitiveness and a prerequisite for intensive social and economic growth [3]. There is no doubt that the future depends on how new knowledge is created, stored and disseminated to address specific challenges related to human security. Thus, knowledge management improves disaster management provided by stakeholders in civil protection, eliminates gaps in the exchange of information. In this context, identifying and comparing key factors of knowledge about disasters will provide an efficient setting for public safety development.

Literature review has shown that a significant number of studies carried out by modern researchers both from Ukraine and abroad are on disaster management and civil protection. The issues on theoretical principles and practical tools for disaster countering have been analysed in the works by the leading researchers, namely: S. Andreiev, M. Andriienko, K. Becker, W. Beck, F. Haetani. Specific features of the civil protection system management have been studied by S. Maistro, F. Oseiia, R. Peliiaguru, V. Sadkovyi, D. Skorupka, A. Terentieva, O. Trush, R. Haig, V. Tishchenko, I. Shpylovyi. Issues of human security in crisis situations have been considered by L.Zhukova，R. Kovalenko, M. Kozyar, V. Kostenko, R. Ratushnyi. Considering the state of natural and man-made security, the current social and political instability in the country, combat operations in eastern Ukraine, the issue of safety of the civilian population during disasters remains extremely crucial, thus, it requires further research.

Better protection of human life, territories, property, and environment justifies the need to apply knowledge management at all stages of the emergency management cycle [4]. The adopted Sendai Framework Program for Disaster Risk Reduction (2015-2030) highlights the important role of knowledge in reducing the level of man-made and natural hazards [5]. No mention has been found in the Ukrainian studies for this area of management, in particular, how to manage people as disaster-related knowledge holders. Thus, the urgency of this issue requires more attention to the ways of addressing it.

Given this, the purpose of this paper is to determine the theoretical and practical foundations for knowledge management, which is considered a tool to ensure the safety of the civilian population during emergency response at the artillery warehouses in Ukraine.

In line with the purpose, the study addressed the tasks of: - exploring the importance of knowledge management for effective neutralization of threats caused by disasters;

- investigating the key knowledge factors related to the main stages of the emergency management cycle, and their classification by categories;

- establishing the indicators of relative importance of knowledge factors, which affect disaster management at the artillery warehouses in Ukraine.

Results. Methodological basis for research involves the provisions of the Civil Protection Code of Ukraine [6], the Law of Ukraine "On National Security of Ukraine" [7], DSTU 3891-99. Emergency Safety. Basic terms and definitions of the concepts [8], in which:

- state policy on national security is aimed at protection of human lives from threats, at supporting safe living conditions, welfare and providing the opportunities for sustainable development of the society and environmental protection;

- protection of the population, territories, and environment from disasters is defined as a function of the state. This function is performed during peacetime and special periods by preventing emergencies, eliminating their consequences and assisting victims;
- safety for the civilian population, as well as for objects of the economy and the environment, presupposes the condition of being protected against danger or loss during disasters.

Ukrainian legislation defines an emergency as a situation in a separate territory, enterprise, organization or water body characterized by a violation of normal living conditions. The violation can be caused by a catastrophe, an accident, a fire, a natural disaster, an epidemic, means of destruction, which endangered the life or health of the population, with a large number of casualties, inability to reside within the area and do business, and caused significant material damage [6]. In responding to an emergency, which is maintained by a long, dynamic, integrated process of planning, organizing, coordinating and implementing appropriate activities, the efforts of stakeholders are determined by a consistent flow of events at different stages of the emergency management cycle. During the stages, stakeholders take measures to reduce the negative effects of the emergency on people, infrastructure, and the environment [4]. Limiting the negative impact of emergencies takes place at certain stages of the emergency management cycle, notably: emergency prevention; emergency response and elimination of consequences; emergency recovery works.

The provisions of current regulations define the emergency prevention as a set of legal, social and economic, political, organizational and technical, sanitary and hygienic measures. During emergency prevention, based on data monitoring along with emergency expertise and forecasting, the risk levels are evaluated [6]. These measures are aimed at regulating natural and man-made safety. In turn, emergency response requires from civil protection stakeholders to be prepared to coordinated actions in accordance with appropriate response plans. At the stage of liquidation of the consequences, people and property are rescued, and dangers that pose a threat to human life or health are eliminated. Since the elimination of the consequences of an emergency is dynamic, in order to make a management decision, the head of the authority, enterprise (institution, organization) must quickly obtain updated information about its current state. Any delay in collecting, accessing or using information on an emergency negatively affects decision-making. At the stage of recovery, works related to the reconstruction of destroyed or damaged buildings and structures of economic entities and households are carried out. Recovery works after the liquidation of an emergency are entrusted to the local governments of the emergency-affected territories. Public funds and local budgets, enterprises (institutions, organizations) are involved in supporting recovery works.

Although there is no way to neutralize all the threats caused by disasters, the authorities, enterprises (institutions, organizations) are still making efforts to minimize them. Their efforts are supported by knowledge of the principles and methods of countermeasures, as well as by the lessons learned on disaster prevention and response. Three main interconnected, consistent categories highlighted by researchers help people gain the necessary awareness of protection against extreme threats; they are: data, information, and knowledge. In our view, the basis for these concepts is data (certain facts taken out of context), information is placed above it (data used in context), and knowledge is at the top. Individual observations (data as unstructured information) can be used to develop information.

Through the perception of the best possible pieces of information (interconnected structured data set), experts understand the intentions, vision and general concept of action of the head of the civil protection stakeholder, which creates new knowledge.

At this stage, having received the information, the manager reviews the existing practical knowledge about dangers, makes managerial decisions, and gives necessary directives to ensure the safety of people. Thus, knowledge is a combination of experience and expert assessments, which set the general 
framework for incorporating new experience and contextual information used by the intelligent system (individual, artificial intelligence). The process, which is a sequence of certain interrelated actions aimed at providing knowledge with additional management value is defined as knowledge management by M. Rudenko [9]. It is a complex and multi-stage process within a certain life cycle, which requires to be managed consciously to maintain some consistency and coordination, and to reach the desired level of effectiveness and efficiency of the defined goals.

Knowledge management is a tool for improving decisionmaking efficiency. In Ukrainian management studies and practice, this issue has been defined as a new concept of knowledge development that contributes to organizational competence building [10]. The main purpose of knowledge management is knowledge acquisition and dissemination, that is elimination of its deficit and increasing its efficiency. Scholars suggest a way to understand the essence of knowledge management, which covers all its components. Thus, I. Sytnyk notes that knowledge management is a key element of the modern management process, which forms new approaches to modelling a holistic management system at all levels of government [11]. Ya. Sikora claims that knowledge management moves from the individual to the global level, consequently, and is possible at the command level if the individual one is developed [12].

Kovalchuk G. considers knowledge management as a process of compilation, application of information, direct knowledge, experience, professional skills to achieve certain goals and objectives that can strengthen the organization and increase its competence [13]. L. Anisimova emphasizes that knowledge management is one of the areas in the management of modern organizations, which aims at accumulating and effective application of intellectual capital [14]. S. Illiashenko considers the knowledge management of the enterprise or institution as a coordinated and interconnected processes of knowledge generating (acquisition) and exploitation [15].

Alyushina N., Amosov O., Vovk Yu., Guzairov M., Illyashenko N., Petru D., Kon M., Kozak V., Komarnytska G., Milner B., Novikova M., Pryimak V., Rudenko M., Seminozhenko V., Smolinska N., Stewart T., Cherkasova I., Drucker P., Schumpeter J., Haiek F., Makhlup F., Shipulina Y. also made their contribution to the study on knowledge management building. The works by these researchers highlight the basic aspects and mechanisms of knowledge management, approaches to improving knowledge management in organizations. By embracing an approach from the abstract to the specific, they report on the basic content of knowledge management and a wide range of options for managerial decisions.

Knowledge allows for collaboration between states regardless of their size and geographical location, in many areas of high complexity and diversity [16]. At a time when the leading countries of the world taking into consideration the bitter experience of the notorious emergencies (radiation accidents at the Chernobyl and Fukushima nuclear power plants, the accident at Russia's largest Saiano-Shushenska hydroelectric power station, hurricane "Katrina" in the USA, a recordbreaking flooding in Venice) are working on new safety technologies based on knowledge management, this concept as a tool to ensure the safety of the population in emergencies has not still gained a profound understanding in Ukraine. With regard to the researchers' ideas, we assume that knowledge management is a process in which the authority, or an enterprise (institution, organization) as stakeholders in the field of civil protection generates, accumulates and exploits knowledge to ensure life safety and hazard-free operation, in particular during emergencies. Knowledge management is associated primarily with professionals, knowledge-holders, as the main part in achieving safety objectives. Knowledge management can play a vital role in delivering accurate and reliable information on the emergency risk through the effective sharing of lessons learned.

Although knowledge about the risks and vulnerabilities of society is well known, knowledge management in emergencies is presented fragmentary, thus, significant gaps in information exchange is highlighted. New knowledge is created on the border of the previous one. Despite the existing knowledge on risk assessment in hazard identification approaches, the desired level of understanding of the ways to access to it and use it to enhance public protection capabilities has not been reached yet. For example, a clear lack of knowledge management was evident during the aftermath of munitions explosions at the artillery warehouses in Ukraine [17]. As it turned out, people could only rely on themselves during the first hours of the emergency. As a result, it has led to allocation of significant funds from the state budget to compensate the affected population, to restore buildings, to strengthen critical infrastructure. This highlights the importance of the application of knowledge management initiatives for emergency response. The key challenge is how to take advantage of knowledge as most of it is "hidden" in the minds of professionals. It is up to professionals whether this knowledge is available to other people or not.

Due to the perceived need to share and acquire knowledge on emergencies, the Institute of Public Administration in the Sphere of Civil Protection has launched a research project "Model". This research project is related to recent emergency response at the artillery warehouses in Ukraine. The research project analyses in detail the causes and consequences of the disaster at the ammunition warehouses in the area of Kalinovka, Vinnytska Oblast, in 2016; it expanded the existing knowledge base to improve the actions of civil protection authorities. In view of high probability of emergencies at the artillery warehouses in Ukraine with large-scale destruction and casualties, key areas of knowledge generation were identified based on the stages of the emergency management cycle (Table 1).

During project implementation, an expert survey of representatives of the task force on emergency management was conducted. To this end, ten respondents aged 36 to 45 with 10 to 20 years of experience in civil protection were interviewed, some of them were with practical experience in research and directly involved in emergency response at the artillery warehouses in Ukraine. Review of the results of the survey showed how knowledge factors affected the emergency management efficiency. In our view, some of them are not determinants for emergency response (environmental, psychophysiological, ethical, moral and others). The following are the key knowledge factors of particular importance for public safety within the stages of the emergency management cycle: legal, infrastructural, financial and economic, resource-based, organizational, social and political, and time.

The legal framework for knowledge in the field is related to the legal provisions on the operation of the state bodies and enterprises (institutions, organizations) in emergencies. Current regulation provides requirements for the construction of buildings in settlements, environmental preservation and protection, better land-use management, and so on. Legal norms for countering disasters are defined in the Civil Protection Code of Ukraine [6], as well as in decrees, regulations and standards. The involved respondents consider the clear application of legal norms as an important aspect of countering an emergency. They believe that at the stage of emergency, prevention legislation is able to support life safety. However, it was noted that from the emergency management perspectives, it is unlikely to develop regulations that would offer the solution for all possible issues of human life and safety. A large number of legislative acts and their inconsistency pose a challenge for government policy on protecting the population and territories of the country against disasters. Legal norms are in need to be regularly updated as with the passage of time, the society faces new challenges and disasters that threaten its safe living. 
The main areas of new knowledge generation to protect the safety of the population at the artillery warehouses in Ukraine

\begin{tabular}{|l|l|l|}
\hline No & \multicolumn{1}{|c|}{$\begin{array}{c}\text { Stages of the disaster } \\
\text { management cycle }\end{array}$} & \multicolumn{1}{c|}{ Areas of knowledge generation } \\
\hline 1. & Emergency prevention & $\begin{array}{l}\text { Clarification of the artillery warehouse crisis profile; development of the possible emergency scenario } \\
\text { with the use of probabilistic methods. } \\
\text { Knowledge factors identification and application at the macro level, which will help minimize the risk of } \\
\text { an emergency. } \\
\text { Assessment and capacity-building of the civil protection forces based on factor analysis }\end{array}$ \\
\hline 2. & Emergency response & $\begin{array}{l}\text { An analysis of the results (item 1) regarding their sensitivity to changes or inaccuracies in source data; } \\
\text { decision stability verification followed by the emergency response plan development. } \\
\text { Implementation of transformative learning and civil protection forces' readiness for practical actions }\end{array}$ \\
\hline 3. & $\begin{array}{l}\text { Elimination of consequences } \\
\text { of disasters }\end{array}$ & $\begin{array}{l}\text { Application of the selected operational management and control techniques to coordinate civil } \\
\text { protection forces' actions to deal with crisis situations taking into account the best practices in the field }\end{array}$ \\
\hline 4. & $\begin{array}{l}\text { Emergency recovery } \\
\text { Determination of the cause of the emergency using fuzzy model tools. } \\
\text { Comprehensive assessment of the impact of the emergency on the population, territory and environment } \\
\text { with the identification and allocation of financial resources for urgent works. } \\
\text { Awareness and assessment of differences in the knowledge application and practical actions taken by } \\
\text { stakeholders }\end{array}$ \\
\hline
\end{tabular}

Issues related to the services, units, systems, special structures and buildings that create the necessary conditions for effective emergency response are among the infrastructural factors of knowledge. Their combination functionally supports the activities of civil protection authorities and is of the utmost importance for effective emergency response. The role of the infrastructural factor remains important throughout all the stages of the emergency management cycle. Good choice of features and qualities of these aspects contributes to the tasks of public safety at times of crisis. The respondents argue that proper infrastructure is vital for effective emergency response. Thus, because of the remoteness of the emergency site, civil protection forces are not always able to arrive and respond timely [18]. Therefore, the potential of the risk-based infrastructure within the administrative territory which is designed to provide safety during disasters should be strengthened.

The financial and economic factor includes management of goods, services, control assets, and others. The financial and economic knowledge factor characterizes the scope of civil protection in terms of total capacity of budgetary sufficiency. Providing public safety during disasters with respect to this factor can be considered as a complex concept with the system of indicators that show financial resource visibility, allocation and utilization. Finance is a vital resource at all stages of the emergency management cycle. Effective financial and economic policies and rapid implementation of the necessary procedures contribute to the proper emergency management. The respondents emphasize the importance of the financial knowledge factor at the stage of emergency prevention. For example, due to the fact that the western part of Ukraine is prone to floods, more effective emergency risk assessment should be carried out, along with addressing the causes of the emergency.

Equipment, tools, technologies, processes, methods, intellectual potential for emergency management relate to the resource knowledge factor. Most emergency response measures are based on resources. Resources facilitate the timely information delivery to the authorities and the public. The maximum impact of the resource knowledge factor is observed at the emergency response stage. At this stage, the focus is on the rescuers' rapid arrival and equipment delivery to the disaster site to assist people and eliminate the consequences of the emergency.

Integrated resource management is needed for recovery works to restore resilience and protect communities in the aftermath of an emergency. Thus, resources are of great importance at all stages of the emergency management cycle. However, the resources for emergency prevention differ from the ones used during emergency response and recovery. The ability of the resource knowledge factor to influence the consequences of emergencies depends on the organizational factor, so that the resource factor is integrated with the organizational knowledge factor. Nevertheless, the respondents claim that the material and technical foundation of civil protection forces does not meet modern requirements, and there is a lack of an adequate logistics reserve system at all government levels to be used in case of emergencies.

The organizational factor of knowledge includes planning, coordination and control undertaken by stakeholders' administrative body over the executors' activities on public safety. The organizational factor is related to the forms and methods of conducting the emergency rescue operations, increasing the responsibility for the readiness to respond, engaging the personnel with the appropriate qualification level.

Arrangements for transportation and storage of means, information exchange of civil protection institutions during communicative interaction also fall into this category. Organizational knowledge is considered important at all stages of the emergency management cycle. The respondents claim that there is a relationship between some drawbacks and appropriate quality of emergency management. The respondents also consider ineffective solutions as the main reason for improper recovery works in the aftermath of an emergency.

The social and political knowledge factor can affect public safety both directly and indirectly. The direct influence of the social and political factor is most evident in the reduction of communities' own resilience to natural and man-made threats. The indirect influence of the social and political factor comes down to the assessment of the level of communities' general safety. This factor is also emerging during a high-profile disaster, which leads to a sharp increase in political interest of some radically-minded actors both within the country and abroad.

The respondents pointed out that the social and political knowledge factor becomes more visible when people are not aware of any possible threats and are not ready to counter them for their own safety. Raising the level of awareness, conscious attitude to their own safety and readiness to maintain it in an emergency is related to this factor. It is also suggested that certain emergencies could have been prevented but some people do not take into account lessons learned from the previous experience. For example, after significant floods in the regions of Zakarpattia and Volyn in Ukraine, people continue to build housing in low-lying areas where there is a threat of another flood. The social and political knowledge factor can be traced throughout the emergency management cycle, which must be carefully studied and taken into account. 
This factor is of concern to society and stakeholders during an emergency and at the stage of recovery works. However, no matter how well society is aware of the threats but has a will to accept and live with them, this situation is seen as a social and political achievement. For instance, the Chernobyl disaster, the largest in the history of nuclear energy, left imprints on the lives of many people who are aware of the threats and have become resilient despite irreparable damage to their health and the environment.

Time factor. The form and measure of all types of motion is time, which shows the duration of the reality and the sequence of changes in the state of all material systems and processes in the world. Investigating knowledge management at the stages of the emergency management cycle, we reached the conclusion that the speed of information search and acquisition is an important parameter of technological solutions; it influences the effectiveness of management decisions. The response to emergencies is dynamic, so decision-makers need to quickly obtain the necessary information about the current state of an emergency. Any delay in knowledge gathering, access, use and distribution has a negative impact on the quality of decisionmaking and therefore on the possible consequences of an emergency. Lack of rapid knowledge sharing may be one of the reasons for the low level of emergency management. Professional development of the specialists due to the new knowledge acquisition affects the speed of decision-making. Acquiring new knowledge and passing it on to others take extra time.

The findings of the research obtained with the expert assessments method, which is considered as one of the most effective modern tools for quality information analysis [19], showed the indicators of relative importance of the key knowledge factors affected the level of public safety during the disaster at the artillery warehouses in Ukraine (Table 2).

The results of the assessment of factor relative importance of the knowledge indicate that social and political $(0.720 \mathrm{frac}-$ tion of a unit) and organizational ( 0.585 fraction of a unit), as well as resource ( 0.500 fraction of a unit) factors are of great importance during emergency management at the artillery warehouses in Ukraine. In turn, infrastructural ( 0.185 fraction of a unit) and legal ( 0.215 fraction of a unit) knowledge factors have been identified as less significant for the provision of public safety during emergency management at the artillery warehouses in Ukraine.

The foregoing confirms the conclusions that emergencies at the artillery warehouses in Ukraine had an adequate public response. It was the response to the effects of how people perceive the frequent emergency events at the artillery warehouses, along with the feedback on the authorities' inefficiency to carry out recovery works and to the mobilization of substantial logistical resources from institutions and organizations, most of which were never involved in the works.

Table 2

Indicators of relative importance of knowledge factors that influenced the level of public safety during emergency management at the artillery warehouses in Ukraine

\begin{tabular}{|l|c|c|}
\hline Knowledge factor & $\begin{array}{c}\text { Total score } \\
\text { determined by } \\
\text { the respondents }\end{array}$ & $\begin{array}{c}\text { Assessment of relative } \\
\text { importance of the } \\
\text { knowledge factor }\end{array}$ \\
\hline Legislative & 192.50 & 0.215 \\
\hline Infrastructural & 194.50 & 0.185 \\
\hline Financial and economic & 175.00 & 0.400 \\
\hline Resource-based & 167.50 & 0.500 \\
\hline Organizational & 162.50 & 0.585 \\
\hline Social and political & 150.00 & 0.720 \\
\hline Time & 190.00 & 0.250 \\
\hline
\end{tabular}

Conclusions. In areas where immediate response is mandatory, knowledge management becomes an important and vital tool for ensuring the availability of information and accessibility to it. It helps to summarize the lessons learned from the past failures and successes and develops the necessary competencies of professionals. As disasters lead to deaths and direct or indirect economic damage, there is an urgent need for the government to build capacity to counter them. In this regard, efforts to overcome emergencies are focused on possible human losses reduction or avoiding, on providing assistance to victims and enabling people to recover quickly from dangers. Emergency management is based on the exploitation of knowledge about threats, nature and patterns of their course, strict and consistent implementation of the measures on response, and elimination of threats as well.

Literature review along with the analysis of the main provisions of regulations, empirical and expert research have made it possible to identify key factors of knowledge within the emergency management cycle. Among knowledge factors, social and political, organizational and resource-based factors proved to be important for ensuring public safety during disasters at the artillery warehouses in Ukraine. However, infrastructural and legal knowledge factors had less impact on human safety. Future research is needed to explore opportunities for improving the management and public safety during recovery and reconstruction after disaster impacts.

\section{References.}

1. Information and analytical summary about emergency events for 2019 (2020). Retrieved from https://www.dsns.gov.ua/ua/ Dovidka-za-kvartal/103179.html.

2. Petrenko, L. (2019). Improvement of qualification of civil protection specialists in the dimension of modern realities. Pedagogy and psychology of vocational education, 1, 95-104. https://doi.org/10.32447/22185186.2019.1.10.

3. Moshek, G., \& Tsipurynda, V. (2016). The role of staff in the innovative development of the enterprise. In A. Mazaraki (Ed.), Proceedings of IX International Business Forum: Problems and Prospects for the Innovation Development of Ukraine, (pp. 122-124). Kyiv, Ukraine: Kyiv National University of Trade and Economics. Retrieved from https:// https://knute. edu.ua/file/MTc=/a23c3cc178b930b594a8eed04c5812e7.pdf. 4. Mykhailov, V. (2017). Ensuring public safety of the united territorial communities using the management cycle in civil protection. In V. Kyibida, \& I. Rozputenko (Eds.), Proceedings of the Scientific and Practical Conference with International Participation: National Values and Interests in Public Administration. V. 1., (pp. 60-64). Kyiv: NADU.

5. Sendai Disaster Risk Reduction Framework for 2015-2030 (2015). Retrieved from https://www.unisdr.org/files/43291 russiansendaiframeworkfordisasterri.pdf.

6. Verkhovna Rada of Ukraine (2013). Code of Civil Protection of Ukraine. Vedomosti of the Verkhovna Rada of Ukraine, 34-35, 458. Retrieved from https://zakon.rada.gov.ua/laws/show/5403-17.

7. Verkhovna Rada of Ukraine (2018). Law of Ukraine "On National Security”. Retrieved from https://zakon.rada.gov.ua/ laws/card/2469-19.

8. DSTU 3891-99. State Standard of Ukraine. Emergency Safety. Basic Terms and Definitions of Concepts (1999). Retrieved from https://dnaop.com/html/2278/doc-ДСТУ 3891-99.

9. Rudenko, M., \& Kryvoruchko, V. (2016). Knowledge management as a competitive advantage of the enterprise. Ekomomica ta Derzhava, 4, 74-78.

10. Kozak, V. (2017). Knowledge Management in the View of Modernization of Public Administration in Ukraine. Collection of scientific works "Public Administration and Local Government”, 3(34), 43-48. Retrieved from http://dridu.dp.ua/vidavnictvo/2017/2017 03(34)/index.html.

11. Sytnyk, Yo. (2017). Knowledge management as a part of the intellectualization of enterprise management systems. Economy and Society, 8, 354-360. 
12. Sikora, Ya. (2017). The use of knowledge management methods for e-learning organization. Information Technologies and Learning Tools, 5, 162-167. https://doi.org/10.33407/itlt. v61i5.1718.

13. Kovalchuk, G. (2015). Knowledge management as a component of the quality of vocational training in the system of social and economic security of the local environment. Higher education, 4-5, 20-37.

14. Anisimova, L., \& Pryimak, V. (2015). Knowledge management technologies in view of quality management implementation. Bulletin of Taras Shevchenko National University of Kyiv. Economics, 7(172), 14-20. https://doi.org/10.17721/17282667.2015/172-7/2.

15. Illiashenko, S. M., Shipulina, Yu. S., Illiashenko, N. S., \& Komarnytska, G.A. (2017). Knowledge management in the system organization's innovative development. Marketing and Management of Innovations, 1, 231-241. https://doi. org/10.21272/mmi.2017.1-21.

16. United Nations organization (2016). Knowledge management in the United Nations system. Retrieved from https://undocs.org/ru/JIU/REP/2016/10.

17. Special topic: fire at the military warehouses in Kalynivka (2017). Vezha. Retrieved from: https://vezha.ua/vybuhy-ukalynivtsi-onovlyuyetsya/.

18. Verkhovna Rada of Ukraine (2017). Order of the Cabinet of Ministers of Ukraine "On Approval of the Strategy for Reforming the State Emergency System of Ukraine”. Retrieved from: https:// zakon.rada.gov.ua/laws/show/61-2017-\%D1\%80\#Text.

19. Bashynska, I. (2015). Using the Method of Expert Evaluation in Economic Calculations. Actual Problems of Economics, 7, 408-412.

\section{Управління знаннями як інструмент забезпечення безпеки населення в надзвичайних ситуаціях}

\section{П. Б. Волянський ${ }^{1}$, В. М. Михайлов ${ }^{1}$, К. І. Шихненко ${ }^{1}$, А. В. Михайлова ${ }^{2}$ \\ 1 - Інститут державного управління у сфері цивільного захисту, м. Київ, Україна, e-mail: mvn2006@ukr.net 2 - Український науково-дослідний інститут у сфері ци- вільного захисту, м. Київ, Україна}

Мета. Полягає у визначенні теоретико-практичних засад управління знаннями як інструменту забезпечення безпеки населення при реагуванні на надзвичайні ситуації в Україні.

Методика. У роботі висвітлюються проблеми управління знаннями для досягнення цілей захисту населення й територій від природних і техногенних небезпек. Досліджуючи проблему, автори використовували загальнонаукові методи дослідження: статистичного аналізу (для відображення показників-змінних впливу надзвичайних ситуацій на життя населення, економіку й довкілля країни); логічного й системного аналізу (для розкриття процесу розвитку та управління знаннями, визначення змісту управління знаннями для забезпечення безпеки населення); узагальнення, аналізу й синтезу (для вивчення наявної системи управління знаннями). Метод індивідуальних експертних оцінок використано під час проведення інтерв'ю з експертами з управління надзвичайними ситуаціями, за результатами якого визначені показники порівняльної важливості факторів знання.

Результати. Встановлено, що управління знаннями $є$ життєво важливим процесом для досягнення цілей щодо захисту населення й територій від небезпек природного та техногенного характеру. Охарактеризовані ключові фактори знань із забезпечення безпеки населення у надзвичайних ситуаціях, що класифіковані за основними категоріями: правовий, інфраструктурний, фінансовоекономічний, ресурсний, організаційний, соціально-політичний, часовий. Встановлені показники порівняльної важливості досліджених факторів знання, що впливають на рівень безпеки людей у ході ліквідації надзвичайних ситуації в Україні.

Наукова новизна. На основі логічного аналізу розкрита сутність управління знаннями для забезпечення безпеки населення у процесі ліквідації надзвичайної ситуації в Україні. Сформульовано поняття «управління знаннями для забезпечення безпеки населення у надзвичайних ситуаціях», в якому акцент робиться на тому, що це процес, у ході якого орган влади, підприємство (установа, організація), як зацікавлений суб'єкт сфери цивільного захисту, генерує й накопичує знання з метою їх використання в інтересах забезпечення безпечного життя і діяльності населення. Виявлені ключові фактори знань із забезпечення безпеки населення у процесі ліквідації надзвичайних ситуацій (правовий, інфраструктурний, фінансово-економічний, ресурсний, організаційний, соціально-політичний, часовий) та встановлено, що вони впливають на рівень безпеки населення на всіх етапах циклу управління надзвичайними ситуаціями. Водночас було з'ясовано, що соціально-політичний, організаційний і ресурсний фактори знань мають особливе значення під час ліквідації надзвичайних ситуацій.

Практична значимість. Отримані результати можуть бути враховані керівниками органів влади, підприємств (установ, організацій), діяльність яких пов'язана з організацією та здійсненням заходів з питань цивільного захисту населення, під час підготовки й ліквідації надзвичайних ситуацій, що забезпечуватиме підвищення рівня безпеки людей.

Ключові слова: надзвичайна ситуація, безпека населення, фактори знань, управління знаннями

\section{Управление знаниями как инструмент обеспечения безопасности населения в чрезвычайных ситуациях}

\section{П. Б. Волянский ${ }^{1}$ В. Н. Михайлов ${ }^{1}$, Е. И. Шихненко ${ }^{1}$, А. В. Михайлова ${ }^{2}$}

1 - Институт государственного управления в сфере гражданской защиты, г. Киев, Украина, e-mail: mvn2006@ukr. $\underline{\text { net }}$

2 - Украинский научно-исследовательский институт гражданской защиты, г. Киев, Украина

Цель. Заключается в определении теоретико-практических основ управления знаниями как инструмента обеспечения безопасности населения при реагировании на чрезвычайные ситуации в Украине.

Методика. В работе освещаются проблемы управления знаниями для достижения целей защиты населения и территорий от природных и техногенных опасностей. Исследуя проблему, авторы использовали общенаучные методы исследования: статистического анализа (для диагностики влияния чрезвычайных ситуаций на жизнь населения, экономику и окружающую среду страны); логического и системного анализа (для раскрытия процесса развития и управления знаниями, определения содержания управления знаниями для обеспечения безопасности населения); обобщения, анализа и синтеза (для изучения существующей системы управления знаниями). Метод индивидуальных экспертных оценок использован при проведении интервью с экспертами по управлению чрезвычайными ситуациями, по результатам которого определены показатели сравнительной важности факторов знаний. 
Результаты. Установлено, что управление знаниями является жизненно важным процессом для достижения целей по защите населения и территорий от опасностей природного и техногенного характера. Охарактеризованы ключевые факторы знаний по обеспечению безопасности населения в чрезвычайных ситуациях, которые классифицированы по основным категориям: правовой, инфраструктурный, финансово-экономический, ресурсный, организационный, социально-политический, временной. В результате экспертного исследования установлены показатели сравнительной важности исследованных факторов знаний, которые влияют на безопасность людей в ходе ликвидации чрезвычайных ситуаций в Украине.

Научная новизна. На основе логического анализа раскрыта сущность управления знаниями для обеспечения безопасности населения в процессе ликвидации чрезвычайных ситуаций в Украине. Сформулировано понятие «управление знаниями для обеспечения безопасности населения в чрезвычайных ситуациях», в котором акцент делается на том, что это процесс, в ходе которого орган, предприятие (учреждение, организация) как заинтересованный субъект сферы гражданской защиты, генерирует и накапливает знания с целью их использования в инте- ресах обеспечения безопасной жизнедеятельности населения. Выявлены ключевые факторы знаний по обеспечению безопасности населения в процессе ликвидации чрезвычайных ситуаций (правовой, инфраструктурный, финансово-экономический, ресурсный, организационный, социально-политический, временной), а также установлено их влияние на уровень безопасности населения на всех этапах цикла управления чрезвычайными ситуациями. В то же время было установлено, что социально-политический, организационный и ресурсный факторы знаний имеют особое значение при ликвидации чрезвычайных ситуаций.

Практическая значимость. Полученные результаты могут быть учтены руководителями органов власти, предприятий (учреждений, организаций), деятельность которых связана с организацией и осуществлением мероприятий по вопросам гражданской защиты, во время подготовки к ликвидации чрезвычайных ситуаций, что повысит уровень безопасности населения.

Ключевые слова: чрезвычайная ситуация, безопасность населения, факторы знаний, управление знаниями

Recommended for publication by M. Andriienko, Doctor of Public Administration. The manuscript was submitted 09.02.20. 